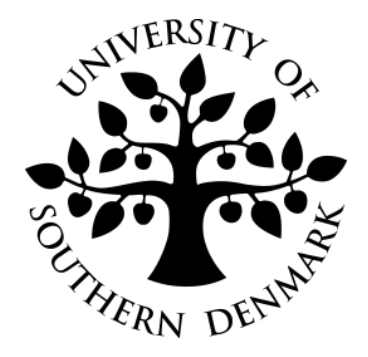

\title{
In fatal pursuit of immortal fame: Peer competition and early mortality of music composers
}

\author{
by \\ Karol Jan Borowiecki and Georgios Kavetsos
}

Discussion Papers on Business and Economics

No. $6 / 2015$

FURTHER INFORMATION

Department of Business and Economics Faculty of Business and Social Sciences University of Southern Denmark Campusvej 55, DK-5230 Odense M

Denmark 


\title{
In fatal pursuit of immortal fame:
}

\section{Peer competition and early mortality of music composers}

\author{
Karol Jan Borowiecki ${ }^{\text {a, }}{ }^{*}$ and Georgios Kavetsos ${ }^{b}$ \\ ${ }^{a}$ University of Southern Denmark, Department of Business and Economics, Denmark. \\ ${ }^{b}$ London School of Economics, Department of Social Policy, Houghton Street, London, WC2A 2AE, \\ UK. \\ * Corresponding author. E-mail: kjb@sam.sdu.dk.
}

\begin{abstract}
We investigate the impact of peer competition on longevity using a unique historical data set of 144 prominent music composers born in the $19^{\text {th }}$ century. We approximate for peer competition measuring (a) the number or (b) the share of composers located in the same area and time, (c) the time spent in one of the main cities for classical music, and (d) the quality of fellow composers. These measures imply that composers' longevity is reduced, if they located in agglomerations with a larger group of peers or of a higher quality. The point estimates imply that, all else equal, a one percent increase in the number of composers reduces composer longevity by about 7.2 weeks. The utilized concentration measures are stronger than the personal factors included in the analysis in determining longevity, implying that individuals' backgrounds have minimal impact on mitigating the effect of experienced peer pressure. The negative externality of peer competition is experienced also in all cities, fairly independent of their size. Our results are reaffirmed using an instrumental variable approach and are consistent throughout a range of robustness tests. Besides the widely known economic benefits associated with competition, these findings suggest that significant negative welfare externalities exist as well.
\end{abstract}

JEL Classification: D12; I12; N90; R11; Z19

Keywords: geographic concentration; well-being; mortality; urban history; culture

\footnotetext{
This paper is a substantially revised version of the working paper "Does Competition Kill? The Case of Classical Composers," Trinity Economics Papers tep1111, 2011. The research idea originated during discussions with Bruno Frey. We are grateful to Christian Danne, Benjamin Elsner, Bruno Frey, Pantelis Koutroumpis, Henry Overman, Sotiris Vandoros for helpful suggestions. We thank the editor Blair Johnson, Hayley MacDonald and three anonymous reviewers for useful comments and suggestions that substantially improved this study.
} 
"Meyerbeer has immortalized himself! But he has spent three years in Paris to get it done."

Letter by Frederic Chopin from $12^{\text {th }}$ December 1831, Paris.

\section{Introduction}

Individuals' longevity is affected by genetic determinants, lifestyle traits and individuals' susceptibility to health-related risk factors (e.g., smoking, drug use, obesity, etc.), environmental conditions (e.g., pollution), and a mixture of socio-economic factors (e.g., income, social status, and status anxiety) (Veenhoven, 2008). This study focuses on the latter and investigates whether the adverse health effects caused by such socio-economic factors are intensified due to intense competition between peers.

Can any systematic difference be observed in the longevity of individuals who face intense competition, which is arguably greater in geographic clusters? If so, what is the causal relationship between peer competition and longevity? These questions are important, as increasing urbanization might, to some extent, explain why depression has reached such epidemic proportions (McManus et al., 2000; National Institute of Mental Health, 2007). To empirically address these questions we use longevity data for a well-identified group of individuals sharing the same specialization, who have in addition exhibited a sufficient extent of geographic clustering: music composers.

Aspiring individuals locate in large geographic clusters to take advantage of the positive externalities associated with agglomerations, primarily related to employment opportunities and productivity gains (Glaeser and Mare, 2001). The high frequency of individual contact within cities fosters the spillover of technological advancements, knowledge and news, leading to higher productivity and thus wages (Glaeser et al., 1992; Black and Henderson, 1999; Mori and Turrini, 2005). The benefits of agglomeration are especially important to artists, whose product can be made more accessible to a wider 
audience via the provision of an appropriate setting, such as galleries, operas, and symphony orchestras (O'Hagan and Borowiecki, 2010). Artists can further be inspired by the aesthetics of cities, which additionally offer an appropriate opportunity to interact, collaborate with, or even be inspired by the work of, colleagues.

Hellmanzik (2010), for example, argues that the quality of output of artists who worked mainly in highly concentrated locations, such as Paris, peaked earlier in their career. Borowiecki (2013) demonstrates that music composers located in geographic clusters were more productive due to interactions with peers; clustering benefits which, however, decrease with very large peer group sizes where competition for access to limited production facilities is particularly high (Borowiecki, 2015).

Music composers of the $18^{\text {th }}$ - and particularly so, those of the $19^{\text {th }}$ century - had a remarkable entrepreneurial drive (Scherer, 2001, 2004). A number of reasons, arguably demand-driven, led to this (Borowiecki, 2012). First, composers were able to offer their product to a wider, and geographically diverse, audience following the expansion of the middle class in the late $18^{\text {th }}$ century onwards. This eventually led to the creation of newlybuilt concert halls in the main cities for music, where concert performances could now satisfy this demand - such performances were to that point only taking place in churches. Second, in combination with technological developments and advances in manufacturing making music instruments more accessible, this emerging middle class demanded educational services from composers; e.g., piano lessons. They were not the exception to the rule though, as they were exposed to particularly intense competition with peers for access to limited production facilities within a city. For example, by the beginning of the 19th century, most European and North American cities had a single concert hall with a domicile symphonic orchestra and $a$ single opera house with a local opera company (Borowiecki, 2015). Even very large cities usually did not have more than one concert hall or opera house; hence only one composer at a 
time could have his works rehearsed and performed at those facilities.

It is likely that this limited access to production resources may have triggered increased stress levels; presumably more so in cities with a greater number of peers. Stress or status anxiety could result also from other sources, such as unfulfilled expectations and the lack of recognition by one's peers - especially in music clusters where the most skilled peers are based, making it even harder for one to excel. We argue that the concentration of such talent is likely to have had adverse effects in terms of health and well-being, attributed to the continuous mental strain individuals go through in order to achieve their aspirations, and are even more intensified in settings where one's peers thrive. After all, the behavioural sciences suggest that relative, not absolute, outcomes matter (Kahneman and Tversky, 1979; Rayo and Becker, 2007; Thornton, 2008).

We extract data for 144 music composers born in the $19^{\text {th }}$ century and calculate four measures that approximate peer competition: (1) the average number of peers residing in the same location and time; (2) the lifetime average share of peers located in the same location and time; (3) the share of a composer's life spent in one of the main locations for music, where peer group size - and thus competition - is potentially at its highest; and (4) the quality of fellow composers (calculated as the sum of quality indices of all composers located in the same location and time). Across these measures we find evidence pointing towards a negative and non-linear association between peer competition and composer longevity. Our results are robust to a variety of additional specifications that control for additional background variables, including measures of composer's quality, illnesses and incidences of pandemics.

An instrumental variable (IV) model is subsequently estimated in an attempt to tackle potential endogeneity and omitted variables issues; the instrument being the average geographic distance between composers' place of birth and the two main cities for music, Paris and Vienna. We find that composer's centrality of birth is negatively associated with all 
four competition measures. The IV-identification strategy provides some indication that the disclosed association between the employed proxies for competition and longevity is a causal relationship rather than simply a correlation.

Section 2 provides an overview of the relevant literature. Section 3 describes our data and methodology. The results of our analysis are presented in section 4 . Section 5 concludes.

\section{Literature Review}

The relevant literature draws from studies relating socio-economic status with health, and those focusing on the health-related advantages and disadvantages of cities. The literature examining the relationship between socio-economic status and health has mainly focused on the effect of income, with some scholars suggesting a causal link running from income and job status to health (Ettner, 1996; Attanasio and Emmerson, 2003). The Whitehall studies, for example, document an inverse relationship between mortality risk and job seniority among British civil servants, with those ranked lower in the ladder facing mortality rates about three times as high as those of more senior individuals (Marmot et al., 1984; Marmot et al., 1991). A similar relationship has been observed when switching the socio-economic variable to education (Feldman et al., 1989; Lahelma and Valkonen, 1990). A coherent pattern arises when focusing on the unemployed, who experience reduced lengths of life (Iversen et al., 1987; Morris et al., 1994). Others argue that causality runs from health to socio-economic status (Smith 1998, 1999; Meer et al., 2003; Cutler et al., 2006).

In a study on the impact of status on well-being, Redelmeier and Singh (2001a) find that Oscar-winning actors and actresses outlive their nominated peers by about 3.6 years. Interestingly, the opposite holds for Oscar-winning screenwriters (Redelmeier and Singh, 2001b). Further causal evidence running from socio-economic status to health is also provided in Rablen and Oswald (2008), who find that Nobel Prize winners outlive their 
nominated peers by about 1.5 years.

These outcomes may, to some extent, be attributed to increased stress levels caused by competition in the workplace - i.e., job strain. Notably, stress levels appear to have an inverted U-shape, where at the optimum individuals balance capabilities and challenges. Deviations beyond that point - especially if accompanied by high duration (i.e., chronic stress) - are expected to lead to adverse health outcomes (Selye, 1936; Meglino, 1977; Allen et al., 1982; Garhammer, 2002). Carr-Hill et al. (1996), for example, find that GP consultations in the UK increase significantly amongst the unemployed, but especially so for those who recently lost their jobs. Kuhn et al. (2009) find that demand for physical health treatments does not increase following job loss, but document significant increases in expenditures for antidepressants and treatments of mental health problems. These effects are more pronounced amongst men. Browning and Heinesen (2012) find that job loss leads to increased risk of mortality, (attempted) suicide, and hospitalization and death attributed to mental illness, alcohol consumption, and traffic accidents. Vandoros et al. (2014) also document increased levels of traffic accidents following bad financial news.

Furthermore, anxiety is positively correlated with the occurrence of hypertension (Jonas and Lando, 2000), which is in turn positively correlated with depression and negatively correlated with subjective well-being (Ostir et al., 2001; Joynt et al., 2003; Blanchflower and Oswald, 2008; Steptoe et al., 2008). Huppert and Whittington (1995) estimate that those with lower scores on a general health questionnaire eliciting psychiatric symptoms are more likely to be deceased over a 7-year period. Similar evidence is provided for females in Gardner and Oswald (2004). Depression and psychological distress have been found to be significant determinants of coronary heart disease and type II diabetes, amongst other health outcomes (Golden et al., 2004; Everson-Rose and Lewis, 2005). In line with this evidence, Steptoe et al. (2005) argue that positive affect can lead to stabilisation of 
neuroendocrine, inflammatory and cardiovascular activity.

The relationship between cities - and geographical clusters in general - and health is also mixed. On the one hand, 'urban health penalty' proponents suggest that the health of individuals living in cities is worse than that of those living in non-urban areas, mainly because of higher pollution levels (Jedrychowski et al., 1997; Crimi et al., 1999; Freudenberg et al., 2005). Others argue that cities not only offer, on average, better public services including better provision of health and access to health care - but generally provide: (a) better and more diversified provision of consumption goods (e.g., restaurants, theatres); (b) transportation speed, which not only relates to time spent commuting to and from work, but also impacts on the cost and frequency of social contact (Costa and Kahn, 2000); and (c) aesthetics (e.g., architectural beauty, physical setting). These aspects give urban residents a welfare advantage (Glaeser et al., 2001; Sorgaard et al., 2003). To the extent though that stress is exacerbated in cities, this might be partly supporting the empirical evidence suggesting that individuals living in urban areas report decreased levels of subjective wellbeing compared to those living in rural areas (Hudson, 2006; Gerdtham and Johannesson, 2001; Hayo, 2004).

Against this background, this study examines the impact of peer competition, stemming from the concentration of individuals in large geographic clusters, on longevity using data of music composers born in the $19^{\text {th }}$ century.

\section{Data and Methodology}

The results of this study crucially depend on the objectivity and reliability of the sample of composers. With this objective in mind, we gather data on prominent composers based on Murray (2003), who studied human accomplishment in several fields/disciplines, including western music, listing 144 composers born between 1800-1899. This sample of composers is 
derived after much care and consideration and is based on a number of international references.

Previous sources have been argued to be less reliable. For example, a sample of important composers by Gilder and Port (1978) is heavily biased towards English-speaking countries (O'Hagan and Borowiecki, 2010). Risks of country or marketing biases in the selection of composers in Murray (2003) are arguably reduced. This is because of the procedure followed: Murray reduces an initial list of eminent composers by referring to a number of international music dictionaries and encyclopedic sources and, subsequently, derives an index score based on the amount of space allocated to the artist in those reference works. This score is then normalised for all individuals listed in each discipline, so that the lowest score is one and the highest is 100. Murray's extensive approach in deriving this 'human accomplishment list' has been established as a recognized source of famous creators and has been used extensively in past academic research - e.g., Ko and Kim (2008), Hellmanzik (2010) and Borowiecki (2013).

For the sample of composers, we extract detailed background information from Grove Music Online (2009), the leading online source for music research. The employed source dictionary is detailed enough to track composers' lifetime migration patterns and, hence, useful in obtaining measures for the experienced peer group size over their lifetime. The data were obtained manually and constitute an accurate record of the lives of composers covered. Any (unlikely) error of the biographers or during the data extraction, given the studied sample size, can be regarded as negligible as long as it is not systematic. The emerging sample with key background indicators is presented in Table A1 in the Appendix.

The source dictionary refers to musical engagement of family members, if those are of considerable importance. Therefore, in addition to Murray's index score, we also utilise the presence of a music-related engagement of composers' family members as an additional 
measure of their quality (e.g., whether mother played the piano, father acted as conductor, etc.). Music involvement within a composer's family could potentially imply inherited skills and provide some rough indication on his innate ability for music. Alternatively, family members involved in a music-related activity might be capable of providing better training to a young composer or could enable superior access to relevant professional networks. It is therefore likely that composers' quality is positively correlated with music-involvement of his family members.

In order to empirically investigate the association between experienced competition among composers' during their lifetime and longevity we use the following pooled crosssectional model:

Longevity $={ }_{0}+{ }_{1}$ Competition $+{ }_{2}(\text { Competition })^{2}+{ }_{3}$ TBirth $+{ }_{4}$ CBirth $+u$

That is, we regress composer's longevity on measures of experienced peer competition (including a squared term to capture non-linearities), dummy variables indicating the half-century birth period of a composer (TBirth), and a set of region of birth fixed effects (CBirth). Controlling for the birth period is necessary to allow for changes in longevity due to overall improvements in life conditions. Similarly, the inclusion of country of birth controls is important to account for longevity differences between nations; given the size of the sample we group all countries into one of eight geographic regions (see Table 1). Robust standard errors are clustered at the level of the main destination of a composer in order to mitigate biases arising due to geospatial autocorrelation.

Peer competition in equation (1) is measured in four distinct ways. First, for each composer we calculate the average number of other composers based in the same location and year (Number of Composers). Second, we calculate the average share of composers 
resident in the same location and year (Share of Composers) - this measure essentially expresses the Number of Composers in relation to all observed composers in a given year, offering some indication on the relative extent of geographic concentration. Third, we count the share of life a composer spent in one of the geographic clusters with largest composer populations, namely Paris and Vienna (Relative Time spent in Clusters). Our results are robust for Paris or Vienna separately, and also if we extend the list of main centers for music by including London, Moscow and Berlin. This measure takes already some account of the quality of fellow composers, since typically the best are located in geographic clusters (Borowiecki, 2013). Nonetheless, we complement this measure with a variable that reflects the aggregated quality of other composers based in the same location and year (Quality of Composers). To calculate this variable we sum up Murray's index scores for all fellow composers and, as performed previously, express this variable as the lifetime average.

We estimate equation (1) via ordinary least squares (OLS), which however does not resolve biases caused due to the potential endogeneity of the competition variables. There are two reasons why this could be so. First, cities with a high number of composers might attract new composers of higher quality who potentially have superior access to health care or better nutrition. Second, omitted variables, such as the overall life quality in the geographical clusters considered here, could drive or intensify the incidence of both clustering and longevity. One measurable factor that is to some extent related to the overall quality of health in geographic clusters during this period is city size; discussed in the robustness section.

In an attempt to address these concerns we additionally implement an IV-model. We use the average "air-line" geographic distance between composers' place of birth and the two main cities for music: Paris and Vienna. The analysis is conducted during a time-period when travelling, although being fairly possible, was still very constrained and markedly expensive in terms of cost and time; therefore, distance mattered. This is not to say that the covered 
composers have not been mobile. On the contrary, famous composers have exhibited remarkable migration patterns (O’Hagan and Borowiecki, 2010; Borowiecki and O'Hagan, 2012). Our hypothesis is, however, that the destinations of their moves have been potentially affected by geographic distance. The validity of the IV is granted as long as a composer's longevity depends on his experienced concentration intensity or time, and the birth centrality variable impacts his longevity only through its impact on the concentration measures. As a composer locating in the vicinity of Paris and Vienna might experience spill-over effects resulting from proximity (e.g., better access to health care), we treat all locations within a radius of 50-miles from Paris or Vienna as the geographic cluster itself.

The proposed IV-identification seems to satisfy the condition of a random assignment: birth location cannot be influenced by the individual after he was born and births are, to some extent, uniformly dispersed over geographical space. Furthermore, there is relatively little parental choice over location of birth, perhaps due to the nature of the time period when migration was difficult. This argument is supported in Borowiecki (2013), who finds that the number of composers born to parents with a music background is not significantly larger in "music hubs". As a robustness test, we present a reduced form model in the later part of this study and find that birth centrality has no direct significant relationship with longevity, hence providing further indication for the validity of the instrument.

An alternative IV could be the total number of civil war years that affected the country of each location in a 50-year time interval before the composer was born. This alternative IV-specification delivers very similar results to the ones presented here (not reported).

Formally, the first-stage regression in the IV-specification is given by:

Competition $=\alpha_{0}+\alpha_{1}$ Dis $\tan c e_{\text {Birthplace,MainCities }}+\alpha_{3}$ TBirth $+\alpha_{4}$ CBirth $+\varepsilon$ 


\section{Empirical Results}

Table 1 offers summary statistics on composer characteristics within our sample. These include: place of birth, longevity, career duration, ability (i.e., Murray's index score), and indicators for the presence of music-related engagement of family members (Panel A). In Panels B and C, we report the frequency of time period covered and country of birth. Panel D provides statistics on the experienced concentration and clustering measures. There were an average of six additional composers based in the same city in each given year. The relative share of fellow composers located in the same city is 11.6 per cent - i.e., almost 12 per cent of prominent composers were based in the same city in a given year. Around 22 per cent of a composer's life was spent in one of the two main clusters: Paris and Vienna. The share increases to around 30 per cent if one incorporates those in London, Moscow and Berlin. The sum of Murray's index scores of fellow composers based in the same location and time is equal to 50. Panel E provides information on the overall population of cities visited by the composer. The average city size was about 2.3 million and about three-fourths of a composer's working life were spent in cities greater than the average city visited; due to the skewed distribution of population across cities.

Note that the selection of important cluster locations is based on rankings based on the number of occurrences a city has been a composer's primary destination; that is, where he spent the longest part of his working life. Paris is the single most important location in this time-period, followed by Vienna, and then by London, Moscow and Berlin (see Table A2 in the Appendix).

The main results are presented in Table 2. Columns (1)-(4) provide OLS estimates based on equation (1) for each of the four measures of competition: (i) Number of 
Composers, (ii) Share of Composers, (iii) Relative Time Spent in Clusters, and (iv) Quality of

Composers. Competition has a negative and statistically significant impact on longevity, irrespective of how this is measured. The quadratic term, which is found statistically significant in two out of four cases, and is always positive, indicates the competition effect to be non-linear. Geographic concentration is detrimental to the longevity of a composer, but the effect decreases in its strength with further rising concentration intensity. According to these estimates, an additional composer located in the same city throughout life reduces longevity by about 2.2 years, on average. This marginal increase is very large, as on average there were only about six composers located in the same city at the same time (Table 1). Alternatively, one could calculate that a one per cent increase in composers' population is associated with a decreased longevity by 7.2 weeks. The second measure implies that a one percentage point increase in composers located at the same place and time throughout a composer's life reduces his longevity by almost one year. Also here the average composer share of 11.6 percent is relatively low, implying that a one percentage point increase constitutes actually a very large change. Alternatively, one could recalculate the effect as a response to a one percent increase in the average share of composers; yielding a sizable longevity decrease of about 5.9 weeks. The third measure indicates that an extra year spent in one of the predominant clusters for music reduces longevity by about six months. Finally, an increase by one point on Murray's index score of fellow composers located in the same time and place is associated with a drop in longevity by around 2.6 months.

Next, to control for the heterogeneity between composers, we repeat estimations based on equation (1) by including all available composer records (Table 3, Panel A). The estimates of the peer-concentration measures are robust across specifications. Interestingly, Murray's index score and variables indicating family members' engagement in music are not statistically significant in any of our models. The simplest reading of these findings is that the 
concentration measures trump all other potential personal factors in determining longevity and, in particular, that individuals' background have minimal impact on mitigating the effect of experienced peer pressure. Nonetheless, it is important to note that the limited availability of individual level variables means that this finding may not be generalizable.

Notably, a source of imprecision arising from unobserved variables could come from variation in the overall city size. For example, it could be the case that the risk of disease contagion is higher in large cities and therefore the average citizen would suffer from agglomeration diseconomies in terms of poorer health and, consequently, longevity. To account for this, we include additional data on city population collected from Mitchell (1975, 1988), with statistics available for most of the cities covered (typically for the years 1800 , 1850, 1900 and 1950). The series was interpolated for the years in-between and linked with our data on the work location of each composer in every year of his life to estimate the average city population each composer experienced.

Results are reported in Table 3, Panel B. In two out of the four specifications the estimate of average city population is positive, offering some evidence that composers lived longer in larger cities. This result may be attributable to the presence of large city amenities, such as health care infrastructure. The association is estimated at a decreasing rate, although the estimates of the quadratic term are not statistically significant. Even so, each of the four variables measuring peer competition are again estimated with an equally high, if not greater, statistical precision and remain robust in terms of sign and size. These results remain consistent if average city population is measured at logs instead, or if alternative city population measures are included (e.g., the share of a composer's working life spent in cities greater than the average). Overall, these results support the view that - beyond the, arguably, positive impact large cities have on longevity - peer competition experienced in cities constitutes a negative externality on a composer's well-being. 
In an attempt to account for the potential endogeneity of the peer concentration variables, we use the average geographic distance between composers' place of birth and the two main cities for music - i.e., Paris and Vienna - as an IV. Since we have just one instrument, we are forced to restrict the model to one endogeneous variable, which allows us to shed light only on the existence of a linear effect. Table 4 presents the first- and secondstage results for the IV-identification. As can be viewed in the odd-numbered columns, birth centrality is a significant determinant of the first three concentration measures. This is according to our a priori expectations due to the reasonably expensive nature of distance travelling during the sample period. Note that since the number of observations is relatively small, the $10 \%$ significance level is considered as appropriate in this study.

The identification strategy would be invalid if the IV had a direct impact on longevity: a reduced form model of the IV on longevity does not, however, return any statistically significant estimates (see Table A3 in the Appendix). While this is not a perfect test for the fulfillment of the exclusion restriction, it nonetheless provides some support of its validity. We investigate further diagnostic statistics on the quality of the instrument by looking at Under Identification and Weak Identification Tests. In two cases, the Kleibergen-Paap LM statistic is just at the significance boarder, whereas in the strongest specification for the relative time spent in Paris or Vienna, it indicates the model to be well identified. In the Weak Identification Test, we report Cragg-Donald minimum eigenvalue statistic, which have the critical value of 16.38 for a model with one endogenous regressor and one instrument (Stock and Yogo, 2005). The reported Cragg-Donald eigenvalue statistics - reported at the bottom of each of the initial three models - exceed the critical values and hence mitigate the risk of weak instrument bias.

The even columns of Table 4 present the instrumented coefficients, which are negative and statistically significant. One could calculate the longevity loss as a result of a 
one percentage increase in the number of composers located in the city; this would imply a sensible, yet non-negligible shorter duration of life by 10 weeks. The causal effect of a one percent increase in the average share of composers would yield a sizable longevity decrease of about 9.6 weeks. Once again, due to the relatively low mean of the Share of Composers variable, we re-calculate the effect of a one percent, rather than one percentage point, change. The third measure indicates that an extra year spent in one of the predominant clusters for music reduces longevity by about nine months.

Finally, we perform a series of robustness checks to ensure the validity of the main OLS findings, reported in Tables A4 and A5 in the Appendix. Findings do not depend on the inclusion of composers who suffered a long-term illness (Frederic Chopin, Anatol K. Liadov, Albert Roussel and Maurice Ravel). They also do not depend on a composer having spent the majority of his life in locations where his Murray's index score was below average, which is in line with the argument that relative (under-) performance may have been most related to the well-being of a person. Nor do they depend on whether a composer enjoyed early success in his career, defined as the number of important pieces written by the age of 30, using Gilder and Port's (1978) sub-sample of 97 composers listed in Murray (2003). Moreover, these findings do not depend on inclusion of composers who were located in a city where a large epidemic occurred, such as the cholera outbreak in Paris in 1832, or the amount of time a composer has been located in a country where a war occurred (Alban Berg, Henry Cowell, Nikolay Myaskovsky, Carl Orff, Richard Wagner and Ralph Vaughan Williams served in the army during war). Finally, we estimate our models using the exact date of birth of the composer in addition to controlling for the half-century of birth. The notable exception is that composers born later in time live longer, which is a trivial result given, for example, the advancement of medical care, nutrition and public health interventions (e.g., public hygiene, sanitation, water purity) over time (Meeker, 1972; Condran and Crimmins-Gardner, 1978; 
Fogel, 2004). In all cases the statistical significance of the coefficients of the main variables of interest remains unaffected and the estimates change only marginally.

As already mentioned, $19^{\text {th }}$ century composers were also involved in other, musicrelated, occupations. Indeed, 48\% are listed in Grove Music Online (2009) as 'composers' only, while the remaining ones are listed in additional occupations if this involvement was of historical significance: $21 \%$ are recorded also as performers (usually pianists or violinists), $19 \%$ as conductors, and $20 \%$ as teachers. Low occurrence of other activities is not sufficient to empirically explore them further; for example, $6.2 \%$ were critics, two were poets, and two were publishers/editors. Note that as several composers were involved in more than one additional occupation, percentages do not add up to $100 \%$. The main results of the competition measures remain robust after controlling for these additional occupations (Table A5 in the Appendix). The coefficient for performers is negative and in one specification statistically significant, implying that performers may have lived shorter lives, on average. For conductors and teachers the coefficients are consistently positive, and in some cases statistically significant. It is however difficult to assess whether being a conductor or a teacher is conducive to longevity, or perhaps only an indication that those who lived long enough began being involved in such activities - after all, involvement in these activities arguably requires a certain degree of composer maturity.

In a final robustness test, we further consider interacting the competition measures with composer's own quality (Table A5). Encouragingly, the main results of the impact of competition are not affected. The interaction terms between quality and competition measures are negative and occasionally statistically significant. Keeping in mind that our sample covers "winners" only (i.e., prominent composers), we interpret this as an indication that in order to become "better" (obtain a higher index) one needs to strive particularly hard to achieve prominence, which may have adverse health implications. 


\section{Discussion}

This study provides an analysis of the relationship between longevity and location in highly concentrated centers, where job aspirations and competition between peers are arguably at their peak. The lack of adequately disaggregated data on the geography of well-being is overcome by focusing on historical data of location of individuals belonging to a specific profession: $19^{\text {th }}$ century music composers. The use of several measures approximating for peer competition delivers consistent results, implying that composers' longevity was significantly reduced in dense agglomerations for music. These results are robust to a range of robustness tests, including specifications that account for individual level characteristics, such as composer's quality, city population, and occurrence of other events, such as wars or pandemics. We further shed some light on the causality of the relationship between geographic clustering and longevity by applying an IV-approach. All in all, our results support those of previous studies in the literature focusing on the relationship between peer effects and health outcomes (Redelmeier and Singh, 2001a; Rablen and Oswald, 2008), by additionally considering a spatial dimension of these effects.

Anecdotal evidence in support of our results can be found in the biographies of composers who located in main locations for music and other historical records. For example, one of Wagner's rehearsals in Paris was attended by Berlioz, his rival in opera composition. Wagner recalls this encounter in his memoires as follows: "What is certain is that at that time I felt like a little schoolboy next to Berlioz; (...) Berlioz (...) remained silent throughout; he neither encouraged nor discouraged me, but only sighed with a weary smile that 'things in Paris were difficult'”. Arguably, the complex and evolving relationship between the two composers lasted independently of their actual location, however it originated due to the incidence of locating at the same place and time. Interestingly, this particular relationship points at a further source of distress: while Wagner did acknowledge Berlioz's genius and his 
debt to him, Berlioz - during most of his life - withheld from Wagner the recognition that he craved.

The fierce competition between peers often led to depressions and nervous breakdowns, as was the case for Maurice Ravel, who was diagnosed with neurasthenia in 1912 immediately after the gruesome failure of his ballet 'Daphnis et Chloe'. The reason for this? Presumably because Ravel's performance had been overshadowed by an unrivalled concert ten days earlier of Debussy's 'Prelude to the Afternoon of a Faun'. Furthermore, competition often turned friends to rivals. For example, Chopin and Liszt, once close friends, became "frenemies" (Roy, 2014) and their association, plausibly due to the competitive nature of the city, turned into "singularly unpleasant and vindictive".

It is well established that peer effects associated with geographic clusters have positive externalities, such as knowledge spill-over. The first fundamental theorem of welfare economics also argues that competition is indispensable in producing Pareto-optimal outcomes. This study however suggests that the allocative advantages associated with competition could come at a non-negligible cost of a shorter life. This study offers a lower bound of this negative externality; it is possible that peer competition had an adverse effect on numerous other composers who died young and never reached their aspired level of success. To the extent that they published any music work, one could, in principle, identify several of these composers via special music libraries, such as the Petrucci Music Library. Tracking down their biographical details, including information on the time spent in a music cluster and geographical movements, is however not as trivial. Hence, these composers remain unobserved in this research. Another possibility is that certain prospective composers eventually switched careers because of competition and related difficulties in succeeding as a composer. The possibility that composers were well aware of the potential negative effects of relocation on longevity cannot be overlooked either. It might well be the case that these 
individuals were predominantly driven by their aspirations and work-related goals, who also discounted future states of health very highly (Fuchs, 1982).

Limitations. This study does not come without limitations. The IV-specification does not account for non-linear effects and it is very likely that some of the detrimental effects work at a decreasing rate. In addition, despite a range of additionally conducted robustness tests, the coefficients of the concentration variables turn sometimes rather large. This could be attributed to further, unobservable, factors that determine the well-being of composers in each of the cluster locations. It could be the case that the higher extent of competition affects not only the emotional state of each composer, but perhaps also their economic well-being. With a greater number of composers in a music agglomeration, the artists have increased difficulty in finding employment opportunities - this could be partly due to the limited cultural infrastructure that can be found in a typical city at the period studied. Furthermore, alternative income sources, such as private music tuition, may have been relative unattractive due to the over-supply of music teaching services. The fact that artists earn little has been documented before (Abbing, 2002) and it is likely that this is even more the case in a dense agglomeration. Furthermore, the evidence presented is based on a particular sample of working individuals over a specific historical time-period. Thus, any generalizations of the findings of this study should be attempted with caution.

Conclusion. This study presents novel and robust evidence on the adverse effects of peer competition on longevity. The results imply remarkably little variation in the competition effect across composers covered. This indicates that individuals' background, including social standing or quality, may have minimal impact on mitigating the effect of experienced peer pressure. These results indicate that competition, besides the widely known economic benefits, may lead to significant negative welfare externalities as well. 


\section{REFERENCES}

Abbing, H. (2002) Why are Artists Poor. The Exceptional Economy of the Arts. Amsterdam University Press, Amsterdam.

Allen, R.D., Hitt, A.M. and Green, C.R. (1982) Occupational stress and perceived organizational effectiveness in formal groups: An examination of Stress level and stress type, Personal Psychology, 35, 359-370.

Attanasio, O.P. and Emmerson, C. (2003) Mortality, health status, and wealth, Journal of the European Economic Association, 1, 821-850.

Black, D. and Henderson, V. (1999) A theory of urban growth, Journal of Political Economy, $107,252-284$.

Blanchflower, D.G. and Oswald, A.J. (2008) Hypertension and happiness across nations, Journal of Health Economics, 27, 218-233.

Borowiecki, K.J. (2012) Are composers different? Historical evidence on conflict-induced migration (1816-1997), European Review in Economic History, 16(3): 270-91.

Borowiecki, K.J. (2013) Geographic clustering and productivity: An instrumental variable approach for classical composers, Journal of Urban Economics, 73(1): 94-110.

Borowiecki, K.J. (2015) Agglomeration Economies in Classical Music, Papers in Regional Science, forthcoming.

Browning, M. and Heinesen, E. (2012) Effect of job loss due to plant closure on mortality and hospitalization, Journal of Health Economics, 31, 599-616.

Carr-Hill, R.A., Rice, R. and Roland, M. (1996) Socioeconomic determinants of rates of consultation in general practice based on fourth national survey of general practices, British Medical Journal, 312, 1008-1012.

Condran, G.A. and Crimmins-Gardner, E. (1978) Public health measures and mortality in U.S. cities in the late nineteenth century. Human Ecology, 6, 27-54. 
Costa, D. and Kahn, M. (2000) Power couples: Changes in the locational choice of the college educated, 1940-1990, Quarterly Journal of Economics, 115, 1287-1315.

Crimi, P., Boidi, M., Minale, P., Tazzer, C., Zanrdi, S., and Ciprandi, G. (1999) Differences in prevalence of allergic sensitization in urban and rural school children, Annals of Allergy, Asthma and Immunology, 83, 252-256.

Cutler, D., Deaton, A. and Lleras-Muney, A. (2006) The determinants of mortality, Journal of Economic Perspectives, 20, 97-120.

Ettner, S.L. (1996) New evidence on the relationship between income and health, Journal of Health Economics, 15, 67-85.

Everson-Rose, S.A. and Lewis, T.T. (2005) Psychosocial factors and cardiovascular diseases, Annual Review of Public Health, 26, 469-500.

Feldman, J., Makuc, D.M., Kleinman, J.C., and Coroni-Huntley, J. (1989) National trends in educational differences in mortality, American Journal of Epidemiology, 129, 919-933.

Fogel, R.W. (2004) The Escape from Hunger and Premature Death, 1700-2100: Europe, America, and the Third World. Cambridge University Press.

Freudenberg, N., Galea, S. and Vlahov, D. (2005) Beyond urban penalty and urban sprawl: Back to living conditions as the focus of urban health, Journal of Community Health, $30,1-11$.

Fuchs, V.R. (1982) Economic aspect of health. In Fuchs, V.R. (ed.), Time Preferences and Health: An Explanatory Study, University of Chicago Press.

Gardner, J. and Oswald, A.J. (2004) How is mortality affected by money, marriage and stress?, Journal of Health Economics, 23, 1181-1207.

Garhammer, M. (2002) Pace of life and enjoyment of life, Journal of Happiness Studies, 3, 217-256.

Gerdtham, U.G. and Johannesson, M. (2001) The relationship between happiness, health, and 
socio-economic factors: Results based on Swedish microdata, Journal of SocioEconomics, 30, 553-557.

Gilder, E. and Port, J.G. (1978) The Dictionary of Composers and their Music. New York and London: Paddington Press Ltd.

Glaeser, E.L., Kallal, H.D., Scheinkman, J.A. and Shleifer, A. (1992) Growth of cities, Journal of Political Economy, 100, 1126-1152.

Glaeser, E.L., Kolko. J. and Saiz, A. (2001) Consumer city, Journal of Economic Geography, $1,27-50$.

Glaeser, E.L. and David C.M. (2001) Cities and skills, Journal of Labor Economics, 19, 316342.

Golden, S.H., Williams, J.E., Ford, D.E., Yeh, H.C., Paton Sanford, C., Nieto, J., and Brancati, F.L. (2004) Depressive symptoms and the risk of type 2 diabetes: The atherosclerosis risk in communities study, Diabetes Care, 27, 429-435.

Grove Music Online, Oxford Music Online. 2009. Oxford University Press. http://www.oxfordmusiconline.com (accessed March-November 2009).

Hellmanzik, C. (2010) Location matters: Estimating cluster premiums for prominent modern artists, European Economic Review, 54, 199-218.

Hudson, J. (2006) Institutional trust and subjective well-being across the EU, Kyklos, 59, 4362.

Huppert, F.A. and Whittington, J.E. (1995) Symptoms of psychological distress predict 7year mortality, Psychological Medicine, 25, 1073-1086.

Jedrychowski, W., Maugeri, U., and Bianchi, I. (1997) Environmental pollution in central and eastern European countries: A basis for cancer epidemiology, Reviews on Environmental Health, 12, 1-23.

Jonas, B.S. and Lando, J.F. (2000) Negative affect as a prospective risk factor for 
hypertension, Psychosomatic Medicine, 62, 188-196.

Joynt, K.E., Whellan, D.J., and O’Connor, C.M. (2003) Depression and cardiovascular disease: Mechanisms of interaction, Biological Psychiatry, 54, 248-261.

Iversen, L., Andersen, O., Andersen, P.K., Christoffersen, K., and Keiding, N. (1987) Unemployment and mortality in Denmark, 1970-80, British Medical Journal, 295, 879884.

Kahneman and Tversky (1979) Prospect theory: an analysis of decision under risk. Econometrica, 47:263-91

Kaun, D.D. (1991) Writers die young: The impact of work and leisure on longevity, Journal of Economic Psychology, 12, 381-399.

Kuhn, A., Lalive, R. and Zweimüller, J. (2009) The public health costs of job loss, Journal of Health Economics, 28, 1099-1115.

Lahelma, E. and Valkonen, T. (1990) Health and social inequities in Finland and elsewhere, Social Science and Medicine, 31, 257-265.

Marmot, M.G., Davey Smith, G., Stansfeld, S., Patel, C., North F., Head J., White, I., Brunner, E., and Feeney, A. (1991) Health inequalities among British civil servants: the Whitehall II study, Lancet, 337, 1387-1393.

Marmot, M.G., Shipley, M.J. and Rose, G. (1984) Inequalities in death: Specific explanations of a general pattern? Lancet, 323, 1003-1006.

McManus, P., Mant, A., Mitchell, P.B., Montgomery, W.S., Marley, J., and Auland, M.E. (2000) Recent trends in the use of antidepressant drugs in Australia, The Medical Journal of Australia, 173, 458-461.

Meeker, E. (1972) The improving health of the United States, 1850-1915, Explorations in Economic History, 10, 353-373.

Meer, J., Miller, D. and Rosen, H. (2003) Exploring the health-wealth nexus, Journal of 
Health Economics, 22, 713-730.

Meglino, B.M. (1977) Stress and performance: Are they always incompatible?, Supervisory Management, 22, 2-13.

Mitchell, B. R. (1975) European Historical Statistics, 1750-1970, Macmillan, London.

Mitchell, B. R. (1988) International Historical Statistics: The Americas, 1750-1970, Macmillan, London.

Mori, T. and Turrini, A. (2005) Skills, agglomeration and segmentation, European Economic Review, 49, 201-225.

Morris, J.K., Cook, D.G., and Shaper, A.G. (1994) Loss of employment and mortality, British Medical Journal, 308, 1135-1139.

Murray, C. (2003) Human Accomplishment: The Pursuit of Excellence in the Arts and Sciences, 800 B.C. to 1950. New York: Harper Collins.

National Institute of Mental Health (2007) The Numbers Count: Mental Disorders in America.

O'Hagan, J. and Borowiecki, K.J. (2010) Birth location, migration and clustering of important composers: Historical patterns, Historical Methods, 43(2), 81-90.

Ostir, G.V., Markides, K.S., Peek, M.K. and Goodwin, J.S. (2001) The association between emotional well-being and the incidence of stroke in older adults, Psychosomatic Medicine, 63, 210-215.

Rablen, M.D. and Oswald, A.J. (2008) Mortality and immortality: The Nobel Prize as an experiment into the effect of status upon longevity, Journal of Health Economics, 27, $1462-1471$.

Rayo, L. and Becker, G.S. (2007) Habits, peers, and happiness: An evolutionary perspective, American Economic Review, 97, 487-491.

Redelmeier, D.A. and Singh, S.M. (2001a) Survival in academy award-winning actors and 
actresses, Annals of Internal Medicine, 134, 955-962.

Redelmeier, D.A. and Singh, S.M. (2001b) Longevity of screenwriters who win an academy award: Longitudinal study, British Medical Journal, 323, 1491-1496.

Roy, B.K. (2014) Episode 67: Franz Liszt - Chopin's 'Frenemy' http://www.radiochopin.org/episodes/item/526-radio-chopin-episode-67-etudes-op-10nos-4-6-10 (accessed September 2014).

Selye, H. (1936) The Stress of Life, McGraw-Hill, New York.

Smith, J.P. (1998) Socioeconomic status and health, American Economic Review, 88, 192196.

Smith, J.P. (1999) Healthy bodies and thick wallets: The dual relation between health and economic status, Journal of Economic Perspectives, 13, 145-166.

Sorgaard, K.W., Sandlund, M., Heikkila, J., Hansson, L., Vinding, H.R., Bjarnason, O., Bengtsson-Tops, A., Merinder, L., Nilsson, L.L. and Middelboe, T. (2003) Schizophrenia and contact with health and social services: A Nordic multi-centre study, Nordic Journal of Psychiatry, 57, 253-261.

Steptoe, A., O’Donnell, K. Marmot, M., and Wardle, J. (2008) Positive affect and psychosocial processes related to health, British Journal of Psychology, 99, 211-227.

Steptoe, A., Wardle, J., and Marmot, M. (2005) Positive affect and health-related neuroendocrine, cardiovascular, and inflammatory processes, Proceedings of the National Academy of Science of the United States, 102, 6508-6512.

Stock, J.H. and Yogo, M. (2005) Testing for Weak Instruments in Linear IV Regression. In Identification and Inference for Econometric Models: Essays in Honor of Thomas Rothenberg. Donald W.K. Andrews and James H. Stock, New York: Cambridge University Press.

Thornton (2008) The demand for, and impact of, learning HIV status. American Economic 
Review, 98, 1829-1863.

You, J.S. (1987) An econometric study of life expectancy of artists, composers and writers, 1300-1920. In D.V. Shaw et al. (eds) Artistics and Cultural Consumers. Association for Cultural Economics III, pp. 122-132.

Vandoros, S., Kavetsos, G. and Dolan, P. (2014) Greasy roads: The impact of bad financial news on road traffic accidents, Risk Analysis, 34, 556-566.

Veenhoven, R. (2008) Healthy happiness: Effects of happiness on physical health and the consequences for preventive health care, Journal of Happiness Studies, 9, 449-469. 
TABLE 1: Summary of the Included Composers.

\begin{tabular}{|c|c|c|}
\hline & Mean & Standard Deviation \\
\hline & \multicolumn{2}{|c|}{ A: Background Information } \\
\hline Life span (years) & 68.63 & 14.63 \\
\hline Duration of career (years) & 45.13 & 14.70 \\
\hline Murray's index score ${ }^{a}$ & 8.30 & 11.39 \\
\hline Father engaged in music & 0.33 & 0.47 \\
\hline Mother engaged in music & 0.26 & 0.44 \\
\hline \multirow[t]{2}{*}{ Another other family member engaged in music } & 0.22 & 0.41 \\
\hline & \multicolumn{2}{|c|}{ B: Covered Period ${ }^{\mathrm{b}}$} \\
\hline Period 1800-1849 & 0.14 & 0.26 \\
\hline Period 1850-1899 & 0.42 & 0.26 \\
\hline Period 1900-1949 & 0.38 & 0.28 \\
\hline \multirow[t]{2}{*}{ Period 1950-1999 } & 0.07 & 0.12 \\
\hline & \multicolumn{2}{|c|}{ C: Birth Country } \\
\hline British Isles (England, Scotland, Ireland and Wales) & 0.09 & 0.29 \\
\hline France & 0.23 & 0.42 \\
\hline Germanic Countries (Germany, Austria and Switzerland) & 0.19 & 0.40 \\
\hline Italy & 0.06 & 0.24 \\
\hline Russia & 0.14 & 0.35 \\
\hline Eastern Europe (except Russia) & 0.10 & 0.30 \\
\hline Rest of Europe & 0.08 & 0.28 \\
\hline \multirow[t]{2}{*}{ Rest of World } & 0.10 & 0.31 \\
\hline & \multicolumn{2}{|c|}{ D: Peer Competition } \\
\hline Number of composers in the same location and year ${ }^{c}$ & 6.06 & 5.55 \\
\hline Share of composers $(\%)^{d}$ & 11.63 & 11.68 \\
\hline Relative Time Spent in Clusters ${ }^{\mathrm{e}}$ & 21.51 & 27.19 \\
\hline \multirow[t]{2}{*}{ Quality of Composers ${ }^{f}$} & 49.97 & 41.24 \\
\hline & \multicolumn{2}{|c|}{ E: City population } \\
\hline Average city population (millions) & 2.27 & 1.89 \\
\hline Relative time spent in cities that exceed average population (\%) & 74.80 & 24.31 \\
\hline
\end{tabular}

Sources: Data on composers are obtained from Grove Music Online (2009).

Notes: ${ }^{a}$ Murray's index score gauges lifetime achievement ( 1 is lowest and100 highest). ${ }^{\mathrm{b}}$ Time period spans from birth until death. ${ }^{\mathrm{c}}$ Measures the lifetime average of composers located in the same city. ${ }^{\mathrm{d}}$ Share of composers expresses the number of composers in relation to all observed composers in a given year. ${ }^{\mathrm{e}}$ Measures the share of a composer's life that he spent in Paris or Vienna. ${ }^{f}$ Measured as the sum of Murray's index scores of composers located in the same time and place expressed as the lifetime average. 
TABLE 2: Longevity and Geographic Clustering ${ }^{\text {a }}$

\begin{tabular}{|c|c|c|c|c|}
\hline & \multicolumn{4}{|c|}{ Ordinary Least Squares Estimates ${ }^{b}$} \\
\hline & $(1)$ & $(2)$ & $(3)$ & $(4)$ \\
\hline \multirow[t]{2}{*}{ Number of Composers $^{c}$} & $-2.28 * * *$ & & & \\
\hline & $(0.733)$ & & & \\
\hline \multirow[t]{2}{*}{ (Number of Composers) $^{2}$} & $0.072 * *$ & & & \\
\hline & $(0.034)$ & & & \\
\hline \multirow[t]{2}{*}{ Share of Composers ${ }^{\mathrm{d}}$} & & $-0.987 * *$ & & \\
\hline & & $(0.475)$ & & \\
\hline \multirow[t]{2}{*}{$(\text { Share of Composers })^{2}$} & & 0.013 & & \\
\hline & & $(0.01)$ & & \\
\hline \multirow[t]{2}{*}{ Relative Time Spent in Clusters ${ }^{\mathrm{e}}$} & & & $-0.527 * * *$ & \\
\hline & & & $(0.183)$ & \\
\hline \multirow[t]{2}{*}{ (Relative Time Spent in Clusters) $^{2}$} & & & $0.007 * * *$ & \\
\hline & & & $(0.002)$ & \\
\hline \multirow[t]{2}{*}{ Quality of Composers ${ }^{\mathrm{f}}$} & & & & $-0.219 *$ \\
\hline & & & & $(0.115)$ \\
\hline \multirow[t]{2}{*}{ (Quality of Composers) $)^{2}$} & & & & 0.001 \\
\hline & & & & $(0.001)$ \\
\hline Time of Birth Effects & Yes & Yes & Yes & Yes \\
\hline Country of Birth Effects & Yes & Yes & Yes & Yes \\
\hline Observations & 144 & 144 & 144 & 144 \\
\hline $\mathrm{R}^{2}$ & 0.138 & 0.132 & 0.118 & 0.112 \\
\hline
\end{tabular}

Notes: The dependent variable is longevity. Regressions are Ordinary Least Squares (OLS). ${ }^{\text {a }}$ Robust standard errors clustered at the geographic level are reported in parentheses. Each specification contains a constant (not reported). ${ }^{b}$ Estimates are based on the four measures of competition: (1) Number of Composers, (2) Share of Composers, (3) Relative Time Spent in Clusters, and (4) Quality of Composers. ${ }^{c}$ Measures the lifetime average of composers located in the same city. ${ }^{\mathrm{d}}$ Measures the lifetime average share of composers located in the same city. ${ }^{\mathrm{e}}$ Measures the share of a composer's life that he spent in Paris or Vienna. ${ }^{\mathrm{f}}$ Measured as the sum of Murray's index scores of composers located in the same time and place, expressed as the lifetime average.

$* * * p<0.01, * * p<0.05, * p<0.1$. 
TABLE 3: Longevity and Geographic Clustering Controlling for Heterogeneity Between Composers.

\begin{tabular}{|c|c|c|c|c|c|c|c|c|}
\hline & \multirow{2}{*}{\multicolumn{4}{|c|}{$\begin{array}{c}\text { Panel A: Composer Background Variables } \\
\text { OLS Estimates }^{b}\end{array}$}} & \multicolumn{4}{|c|}{ Panel B: Average City Population } \\
\hline & & & & & & OLS Es & nates $^{b}$ & \\
\hline & (1) & (2) & (3) & (4) & (1) & (2) & (3) & (4) \\
\hline Number of Composers $^{c}$ & $\begin{array}{c}-2.248 * * * \\
(0.768)\end{array}$ & & & & $\begin{array}{c}-2.936^{* * *} \\
(0.721)\end{array}$ & & & \\
\hline (Number of Composers) $^{2}$ & $\begin{array}{l}0.069 * \\
(0.035)\end{array}$ & & & & $\begin{array}{c}0.096^{* * * *} \\
(0.035)\end{array}$ & & & \\
\hline Share of Composers ${ }^{\mathrm{d}}$ & & $\begin{array}{c}-0.984 * \\
(0.499)\end{array}$ & & & & $\begin{array}{l}-1.217 * * * \\
(0.439)\end{array}$ & & \\
\hline${\text { (Share of Composers })^{2}}^{2}$ & & $\begin{array}{c}0.013 \\
(0.011)\end{array}$ & & & & $\begin{array}{c}0.017^{*} \\
(0.01)\end{array}$ & & \\
\hline Relative Time Spent in Clusters ${ }^{\mathrm{e}}$ & & & $\begin{array}{c}-0.538 * * * \\
(0.187)\end{array}$ & & & & $\begin{array}{c}-0.506^{* *} \\
(0.219)\end{array}$ & \\
\hline (Relative Time Spent in Clusters) $^{2}$ & & & $\begin{array}{c}0.007 * * * \\
(0.002)\end{array}$ & & & & $\begin{array}{c}0.007 * * \\
(0.003)\end{array}$ & \\
\hline Quality of Composers ${ }^{\mathrm{f}}$ & & & & $\begin{array}{l}-0.23 * \\
(0.134)\end{array}$ & & & & $\begin{array}{c}-0.309 * * * \\
(0.108)\end{array}$ \\
\hline (Quality of Composers) $^{2}$ & & & & $\begin{array}{c}0.001 \\
(0.001)\end{array}$ & & & & $\begin{array}{c}0.001^{*} \\
(0.0007)\end{array}$ \\
\hline Murray's Index Score & $\begin{array}{l}-0.023 \\
(0.14)\end{array}$ & $\begin{array}{l}-0.033 \\
(0.141)\end{array}$ & $\begin{array}{c}0.012 \\
(0.133)\end{array}$ & $\begin{array}{c}0.073 \\
(0.166)\end{array}$ & & & & \\
\hline Father's Music Engagement & $\begin{array}{l}-1.349 \\
(2.197)\end{array}$ & $\begin{array}{l}-1.138 \\
(2.099)\end{array}$ & $\begin{array}{l}-0.709 \\
(2.171)\end{array}$ & $\begin{array}{l}-1.415 \\
(2.187)\end{array}$ & & & & \\
\hline Mother's Music Engagement & $\begin{array}{l}-0.567 \\
(2.652)\end{array}$ & $\begin{array}{l}-1.238 \\
(2.694)\end{array}$ & $\begin{array}{l}-0.631 \\
(3.144)\end{array}$ & $\begin{array}{c}-1.213 \\
(2.7)\end{array}$ & & & & \\
\hline Family's Music Engagement & $\begin{array}{l}-0.927 \\
(2.512)\end{array}$ & $\begin{array}{l}-0.605 \\
(2.504)\end{array}$ & $\begin{array}{l}-1.912 \\
(2.395)\end{array}$ & $\begin{array}{l}-0.672 \\
(2.473)\end{array}$ & & & & \\
\hline Average City Population (thousands) & & & & & $\begin{array}{c}6.828 * * \\
(3.375)\end{array}$ & $\begin{array}{c}5.418 \\
(3.297)\end{array}$ & $\begin{array}{c}4.843 \\
(3.147)\end{array}$ & $\begin{array}{l}6.133^{*} \\
(3.499)\end{array}$ \\
\hline (Average City Population) $^{2}$ & & & & & $\begin{array}{l}-0.537 \\
(0.429)\end{array}$ & $\begin{array}{l}-0.365 \\
(0.42)\end{array}$ & $\begin{array}{l}-0.392 \\
(0.387)\end{array}$ & $\begin{array}{l}-0.499 \\
(0.433)\end{array}$ \\
\hline Time of Birth Effects & Yes & Yes & Yes & Yes & Yes & Yes & Yes & Yes \\
\hline Country of Birth Effects & Yes & Yes & Yes & Yes & Yes & Yes & Yes & Yes \\
\hline Observations & 144 & 144 & 144 & 144 & 139 & 139 & 139 & 139 \\
\hline $\mathrm{R}^{2}$ & 0.142 & 0.136 & 0.122 & 0.118 & 0.197 & 0.181 & 0.146 & 0.165 \\
\hline
\end{tabular}

Notes: The dependent variable is longevity. Regressions are Ordinary Least Squares (OLS). ${ }^{\text {a }}$ Robust standard errors clustered at the geographic level are reported in parentheses. Each specification contains a constant (not reported). ${ }^{\mathrm{b}}$ OLS estimates are based on the 4 measures of competition: (i) Number of Composers, (ii) Share of Composers, (iii) Relative Time Spent in Clusters, and (iv) Quality of Composers. ${ }^{\mathrm{c}}$ Measures the lifetime average of composers located in the same city. ${ }^{\mathrm{d}}$ Measures the lifetime average share of composers located in the same city. ${ }^{\mathrm{e}}$ Measures the share of a composer's life that he spent in Paris or Vienna. ${ }^{\mathrm{f}}$ Measured as the sum of Murray's index scores of composers located in the same time and place, expressed as the lifetime average.

*** $p<0.01, * * p<0.05, * p<0.1$. 
TABLE 4: Results from the IV-Approach on Longevity and Geographic Clustering.

\begin{tabular}{|c|c|c|c|c|c|c|c|c|}
\hline Dependent Variable & $\begin{array}{l}\text { Number of } \\
\text { Composers }\end{array}$ & Longevity & $\begin{array}{c}\text { Share of } \\
\text { Composers }\end{array}$ & Longevity & $\begin{array}{l}\text { Relative time } \\
\text { spent in Clusters }\end{array}$ & Longevity & $\begin{array}{c}\text { Sum of Indices of } \\
\text { Fellow Composers } \\
\text { Quality }\end{array}$ & Longevity \\
\hline Birth Centrality ${ }^{a}$ & $\begin{array}{l}0.097^{*} \\
(0.048)\end{array}$ & & $\begin{array}{l}0.194^{*} \\
(0.106)\end{array}$ & \multirow{5}{*}{$\begin{array}{l}-1.598^{*} \\
(0.917)\end{array}$} & $\begin{array}{c}0.344^{* *} \\
(0.131)\end{array}$ & \multirow{5}{*}{$\begin{array}{c}-0.787 * * \\
(0.35)\end{array}$} & $\begin{array}{c}0.545 \\
(0.384)\end{array}$ & \multirow[b]{5}{*}{$\begin{array}{l}-0.568 \\
(0.416)\end{array}$} \\
\hline Number of Composers ${ }^{b}$ & & $\begin{array}{l}-3.182 * \\
(1.719)\end{array}$ & & & & & & \\
\hline Share of Composers ${ }^{c}$ & & & & & & & & \\
\hline $\begin{array}{l}\text { Relative time spent in } \\
\text { Cluster }^{\mathrm{d}}\end{array}$ & & & & & & & & \\
\hline Quality of Composers ${ }^{\mathrm{e}}$ & & & & & & & & \\
\hline Time of Birth Effects & Yes & & Yes & & Yes & & Yes & \\
\hline Country of Birth Effects & Yes & & Yes & & Yes & & Yes & \\
\hline Observations & 144 & & 144 & & 144 & & 144 & \\
\hline$R^{2}$ & 0.772 & & 0.743 & & 0.702 & & 0.700 & \\
\hline Under Identification Test & 2.248 & & 2.062 & & 2.804 & & 1.366 & \\
\hline Weak Identification Test & 33.424 & & 25.473 & & 16.966 & & 14.354 & \\
\hline
\end{tabular}

Notes: Robust standard errors are reported in parentheses. Each specification contains a constant which is not reported. ${ }^{\text {a }}$ Birth Centrality measures the average distance between a composer's place of birth and the two main destinations for music (Paris and Vienna). ${ }^{b}$ Measures the lifetime average of composers located in the same city. ${ }^{\mathrm{c}}$ Measures the lifetime average share of composers located in the same city. ${ }^{\mathrm{d}}$ Measures the share of a composer's life that he spent in Paris or Vienna. ${ }^{\mathrm{e}}$ Measured as the sum of Murray's index scores of composers located in the same time and place, expressed as the lifetime average.

IV-first-stage results presented in uneven columns.

$* * * p<0.01, * * p<0.05, * p<0.1$. 


\section{APPENDIX}

TABLE A1: Summary of all Composers Included in the Study

\begin{tabular}{|c|c|c|c|c|c|c|c|}
\hline Name & $\begin{array}{l}\text { Birth } \\
\text { Year }\end{array}$ & City of Birth & $\begin{array}{l}\text { Primary Work } \\
\text { Location } \\
\end{array}$ & Longevity & $\begin{array}{c}\text { Share of } \\
\text { Composers }\end{array}$ & $\begin{array}{l}\text { Number of } \\
\text { Composers }\end{array}$ & $\begin{array}{c}\text { Relative Time Spent } \\
\text { in Paris or Vienna }\end{array}$ \\
\hline Adam, Adolphe & 1803 & Paris & Paris & 53 & 36.6 & 11.9 & 0.53 \\
\hline Albeniz, Isaac & 1860 & Camprodon & Barcelona & 49 & 3.3 & 1.9 & 0.02 \\
\hline Alfano, Franco & 1875 & Posillipo & Turin & 79 & 1.8 & 1.2 & 0.00 \\
\hline $\begin{array}{l}\text { Arensky, Anton } \\
\text { Stepanovich }\end{array}$ & 1861 & Novgorod & Moscow & 45 & 5.1 & 3.0 & 0.00 \\
\hline Auric, Georges & 1899 & Lodève & Paris & 83 & 20.0 & 9.9 & 0.84 \\
\hline $\begin{array}{l}\text { Balakirev, Mily } \\
\text { Alekseyevich }\end{array}$ & 1836 & Nizhniy Novgorod & St Petersburg & 74 & 9.2 & 4.5 & 0.00 \\
\hline Bartok, Bela & 1881 & Nagyszentmiklos & Budapest & 64 & 5.0 & 3.4 & 0.06 \\
\hline Bax, Sir Arnold & 1883 & Streatham & London & 70 & 5.9 & 4.5 & 0.00 \\
\hline Bellini, Vincenzo & 1801 & Catania & Milan & 34 & 17.3 & 5.5 & 0.09 \\
\hline Benoit, Peter & 1835 & Harlebeke & Antwerp & 65 & 5.2 & 2.0 & 0.02 \\
\hline Berg, Alban & 1885 & Vienna & Vienna & 50 & 7.6 & 5.8 & 0.48 \\
\hline Berlin, Irving & 1888 & Mogilyov & New York & 99 & 10.5 & 5.8 & 0.00 \\
\hline Berlioz, Hector & 1803 & Cote-Saint-Andre & Paris & 66 & 38.1 & 13.1 & 0.53 \\
\hline Bizet, Georges & 1838 & Paris & Paris & 37 & 38.3 & 14.6 & 0.43 \\
\hline Bliss, Sir Arthur & 1891 & London & London & 84 & 5.2 & 2.6 & 0.00 \\
\hline Bloch, Ernest & 1880 & Geneva & San Francisco & 79 & 2.5 & 1.9 & 0.01 \\
\hline Boito, Arrigo & 1842 & Padua & Milan & 75 & 3.7 & 2.1 & 0.00 \\
\hline Borodin, Aleksandr & 1833 & St Petersburg & St Petersburg & 54 & 11.2 & 4.7 & 0.00 \\
\hline Brahms, Johannes & 1833 & Hamburg & Vienna & 64 & 7.4 & 3.5 & 0.56 \\
\hline Bruch, Max & 1838 & Cologne & Berlin & 82 & 3.0 & 2.2 & 0.00 \\
\hline Bruckner, Anton & 1824 & Linz & Vienna & 72 & 4.1 & 2.0 & 0.40 \\
\hline Bruneau, Alfred & 1857 & Paris & Paris & 76 & 27.0 & 18.4 & 0.68 \\
\hline Busoni, Ferruccio & 1866 & Empoli & Berlin & 58 & 5.2 & 3.6 & 0.02 \\
\hline Casella, Alfredo & 1883 & Turin & Rome & 64 & 10.3 & 7.7 & 0.20 \\
\hline Chabrier, Alexis & 1841 & Ambert & Paris & 53 & 36.0 & 16.2 & 0.62 \\
\hline Chausson, Ernest & 1855 & Paris & Paris & 44 & 30.3 & 16.9 & 0.43 \\
\hline Chavez, Carlos & 1899 & Mexico City & Mexico City & 79 & 0.8 & 0.5 & 0.00 \\
\hline $\begin{array}{l}\text { Chopin, Fryderyk } \\
\text { Franciszek }\end{array}$ & 1810 & Warsaw & Paris & 39 & 39.4 & 13.6 & 0.23 \\
\hline Cornelius, C. Peter & 1825 & Mainz & Munich & 49 & 1.9 & 0.7 & 0.12 \\
\hline Cowell, Henry & 1897 & California & Berkeley & 68 & 6.1 & 2.5 & 0.00 \\
\hline Cui, Cesar & 1835 & Vilnius & St Petersburg & 83 & 8.7 & 4.4 & 0.00 \\
\hline $\begin{array}{l}\text { Dargomizhsky, } \\
\text { Aleksandr Sergeyevich }\end{array}$ & 1813 & Troitskoye & St Petersburg & 56 & 6.4 & 2.2 & 0.00 \\
\hline David, Felicien & 1810 & Cadenet & Paris & 66 & 39.3 & 13.8 & 0.62 \\
\hline Debussy, Claude & 1862 & St Germain-en-Laye & Paris & 56 & 27.0 & 17.4 & 0.70 \\
\hline Delibes, Clement & 1836 & St Germain du Val & Paris & 54 & 38.5 & 15.7 & 0.70 \\
\hline Delius, Frederick & 1862 & Bradford & Paris & 72 & 17.5 & 11.8 & 0.38 \\
\hline Dohnanyi, Ernst von & 1877 & Bratislava & Budapest & 83 & 4.1 & 2.8 & 0.00 \\
\hline Dukas, Paul & 1865 & Paris & Paris & 70 & 26.0 & 18.2 & 0.70 \\
\hline Duparc, Henri & 1848 & Paris & Paris & 84 & 37.2 & 15.4 & 0.20 \\
\hline
\end{tabular}


TABLE A1: Summary of all Composers Included in the Study

\begin{tabular}{|c|c|c|c|c|c|c|c|}
\hline Name & $\begin{array}{l}\text { Birth } \\
\text { Year }\end{array}$ & City of Birth & $\begin{array}{c}\text { Primary Work } \\
\text { Location }\end{array}$ & Longevity & $\begin{array}{c}\text { Share of } \\
\text { Composers }\end{array}$ & $\begin{array}{l}\text { Number of } \\
\text { Composers }\end{array}$ & $\begin{array}{l}\text { Relative Time Spent } \\
\text { in Paris or Vienna }\end{array}$ \\
\hline Durey, Louis & 1889 & Paris & St. Tropez & 89 & 2.8 & 2.2 & 0.08 \\
\hline Dvorak, Antonin & 1841 & Nelahozeves & Prague & 63 & 5.2 & 2.9 & 0.02 \\
\hline Elgar, Edward & 1857 & Worcester & London & 77 & 7.4 & 5.3 & 0.00 \\
\hline Ellington, Duke & 1899 & Washington & New York & 74 & 10.4 & 4.6 & 0.00 \\
\hline Enesco, Georges & 1881 & Liveni Virnav & Paris & 74 & 21.3 & 14.7 & 0.69 \\
\hline Falla, Manuel de & 1876 & Cadiz & Granada & 70 & 4.6 & 3.7 & 0.11 \\
\hline Faure, Gabriel & 1845 & Pamiers & Paris & 79 & 29.7 & 17.4 & 0.72 \\
\hline Fibich, Zdenek & 1851 & Všebo?ice & Prague & 50 & 5.7 & 2.7 & 0.02 \\
\hline $\begin{array}{l}\text { Flotow, Friedrich } \\
\text { Freiherr von }\end{array}$ & 1812 & Toitendorf & Paris & 71 & 21.0 & 7.1 & 0.32 \\
\hline Franck, Cesar & 1822 & Liege & Paris & 68 & 39.1 & 15.3 & 0.71 \\
\hline Franz, Robert & 1815 & Halle & Leipzig & 77 & 0.0 & 0.0 & 0.00 \\
\hline Gade, Niels Wilhelm & 1817 & Copenhagen & Copenhagen & 73 & 3.2 & 1.2 & 0.00 \\
\hline Gerhard, Roberto & 1896 & Valls & Cambridge & 74 & 0.2 & 0.0 & 0.00 \\
\hline Gershwin, George & 1898 & New York & New York & 39 & 8.7 & 6.6 & 0.00 \\
\hline $\begin{array}{l}\text { Glazunov, Aleksandr } \\
\text { Konstantinovich }\end{array}$ & 1865 & St Petersburg & St Petersburg & 71 & 9.5 & 6.4 & 0.11 \\
\hline $\begin{array}{l}\text { Glier, Reingol'd } \\
\text { Moritsevich }\end{array}$ & 1875 & Kiev & Moscow & 81 & 3.6 & 2.3 & 0.00 \\
\hline $\begin{array}{l}\text { Glinka, Mikhail } \\
\text { Ivanovich }\end{array}$ & 1804 & Novospasskoye & St Petersburg & 53 & 19.8 & 6.4 & 0.17 \\
\hline Gottschalk, Louis & 1829 & New Orleans & Paris & 40 & 9.7 & 3.0 & 0.05 \\
\hline $\begin{array}{l}\text { Gounod, Charles- } \\
\text { Francois }\end{array}$ & 1818 & Paris & Paris & 75 & 36.7 & 14.6 & 0.60 \\
\hline Granados, Enrique & 1867 & Lerida & Barcelona & 49 & 5.3 & 4.0 & 0.00 \\
\hline Grieg, Edvard Hagerup & 1843 & Bergen & Bergen & 64 & 0.4 & 0.2 & 0.00 \\
\hline Haba, Alois & 1893 & Vizovice & Prague & 80 & 3.7 & 2.0 & 0.05 \\
\hline Harris, Roy & 1898 & Chandler & Stockton & 81 & 2.3 & 0.9 & 0.01 \\
\hline Hauer, Josef & 1883 & Wiener Neustadt & Vienna & 76 & 5.4 & 3.7 & 0.63 \\
\hline Hindemith, Paul & 1895 & Frankfurt & $\begin{array}{c}\text { Blonay, } \\
\text { Switzerland }\end{array}$ & 68 & 1.8 & 1.2 & 0.00 \\
\hline Holst, Gustav & 1874 & Cheltenham & London & 60 & 8.1 & 6.1 & 0.00 \\
\hline Honegger, Arthur & 1892 & Le Havre & Paris & 63 & 22.2 & 14.5 & 0.63 \\
\hline Humperdinck, Engelbert & 1854 & Siegburg & Berlin & 67 & 4.8 & 3.3 & 0.03 \\
\hline Ibert, Jacques & 1890 & Paris & Paris & 72 & 20.7 & 12.4 & 0.56 \\
\hline Ives, Charles Edward & 1874 & Danbury & New York & 80 & 7.4 & 4.7 & 0.00 \\
\hline Janacek, Leos & 1854 & Hukvaldy & Brno & 74 & 0.4 & 0.2 & 0.00 \\
\hline Kern, Jerome & 1885 & New York & New York & 60 & 8.3 & 6.1 & 0.00 \\
\hline Kjerulf, Halfdan & 1816 & Oslo & Oslo & 52 & 0.0 & 0.0 & 0.00 \\
\hline Kodaly, Zoltan & 1882 & Kecskemet & Budapest & 85 & 3.2 & 1.9 & 0.00 \\
\hline Koechlin, Charles & 1868 & Paris & Paris & 82 & 22.7 & 16.1 & 0.65 \\
\hline Lalo, Edouard & 1823 & Lille & Paris & 69 & 38.8 & 15.5 & 0.67 \\
\hline Lanner, Josef & 1801 & Vienna & Vienna & 41 & 12.5 & 3.8 & 0.59 \\
\hline Lecocq, Charles & 1832 & Paris & Paris & 86 & 30.1 & 15.5 & 0.71 \\
\hline Leoncavallo, Ruggero & 1857 & Naples & Milan & 62 & 14.1 & 8.3 & 0.21 \\
\hline Liszt, Franz & 1811 & Raiding & Weimar & 75 & 0.5 & 0.2 & 0.00 \\
\hline
\end{tabular}


TABLE A1: Summary of all Composers Included in the Study

\begin{tabular}{|c|c|c|c|c|c|c|c|}
\hline Name & $\begin{array}{l}\text { Birth } \\
\text { Year }\end{array}$ & City of Birth & $\begin{array}{c}\text { Primary Work } \\
\text { Location }\end{array}$ & Longevity & $\begin{array}{c}\text { Share of } \\
\text { Composers }\end{array}$ & $\begin{array}{l}\text { Number of } \\
\text { Composers }\end{array}$ & $\begin{array}{c}\text { Relative Time Spent } \\
\text { in Paris or Vienna }\end{array}$ \\
\hline Lortzing, Albert & 1802 & Berlin & Leipzig & 48 & 4.2 & 1.4 & 0.04 \\
\hline Macdowell, Edward & 1860 & New York & New York & 48 & 2.2 & 1.5 & 0.00 \\
\hline Mackenzie, Alexander & 1848 & Edinburgh & London & 86 & 5.7 & 4.0 & 0.00 \\
\hline Mahler, Gustav & 1860 & Iglau & Vienna & 51 & 4.2 & 2.7 & 0.22 \\
\hline $\begin{array}{l}\text { Malipiero, Gian } \\
\text { Francesco }\end{array}$ & 1882 & Venice & Venice & 91 & 3.0 & 1.6 & 0.01 \\
\hline Martin, Frank & 1890 & Geneva & Amsterdam & 84 & 2.3 & 0.6 & 0.00 \\
\hline Martinu, Bohuslav & 1890 & Policka & Paris & 69 & 13.7 & 8.9 & 0.22 \\
\hline Mascagni, Pietro & 1863 & Livorno & Rome & 82 & 4.5 & 3.0 & 0.02 \\
\hline $\begin{array}{l}\text { Massenet, Jules Emile } \\
\text { Frederic }\end{array}$ & 1842 & Montaud & Paris & 70 & 31.3 & 16.7 & 0.67 \\
\hline Milhaud, Darius & 1892 & Marseilles & Paris & 82 & 19.1 & 10.7 & 0.57 \\
\hline $\begin{array}{l}\text { Musorgsky, Modeste } \\
\text { Petrovich }\end{array}$ & 1839 & Karevo & St Petersburg & 42 & 12.3 & 4.9 & 0.00 \\
\hline Myaskovsky, Nikolay & 1881 & Modlin & Moscow & 69 & 4.1 & 2.8 & 0.00 \\
\hline Nielsen, Carl & 1865 & Sortelung & Copenhagen & 66 & 2.3 & 1.5 & 0.02 \\
\hline Novak, Vitezlsav & 1871 & Kamenice nad Lipou & Prague & 78 & 3.2 & 2.3 & 0.00 \\
\hline Offenbach, Jacques & 1819 & Cologne & Paris & 61 & 41.1 & 14.6 & 0.75 \\
\hline Orff, Carl & 1895 & Munich & Munich & 87 & 0.0 & 0.0 & 0.00 \\
\hline Parker, Horatio & 1864 & Auburndale & New Haven, CT & 55 & 0.6 & 0.4 & 0.00 \\
\hline Pfitzner, Hans & 1869 & Moscow & Munich & 79 & 1.5 & 1.0 & 0.00 \\
\hline Pijper, Willem & 1895 & Zeist & Rotterdam & 53 & 0.3 & 0.3 & 0.00 \\
\hline Piston, Walter & 1894 & Rockland & Boston & 82 & 4.7 & 2.2 & 0.02 \\
\hline Pizzetti, Ildebrando & 1880 & Parma & Rome & 88 & 2.6 & 1.3 & 0.00 \\
\hline Poulenc, Francis & 1899 & Paris & Paris & 64 & 21.1 & 12.7 & 0.70 \\
\hline Prokofiev, Sergey & 1891 & Sontsovka & St Petersburg & 62 & 11.3 & 8.2 & 0.18 \\
\hline Puccini, Giacomo & 1858 & Lucca & Torre de Lago & 66 & 1.8 & 1.4 & 0.00 \\
\hline Rachmaninoff, Serge & 1873 & Oneg & Moscow & 70 & 11.7 & 8.6 & 0.19 \\
\hline Ravel, Maurice & 1875 & Ciboure & Paris & 62 & 25.2 & 19.2 & 0.50 \\
\hline Reger, Max & 1873 & Brand & Leipzig & 43 & 1.1 & 0.9 & 0.00 \\
\hline Respighi, Ottorino & 1879 & Bologna & Rome & 57 & 3.5 & 2.6 & 0.00 \\
\hline Reyer, Ernest & 1824 & Marseilles & Paris & 84 & 35.3 & 15.9 & 0.73 \\
\hline $\begin{array}{l}\text { Rimsky-Korsakov, } \\
\text { Nikolay Andreyevich }\end{array}$ & 1844 & Tikhvin & St Petersburg & 64 & 10.3 & 5.5 & 0.02 \\
\hline Roussel, Albert & 1869 & Tourcoing & Paris & 68 & 12.3 & 9.5 & 0.22 \\
\hline Ruggles, Carl & 1876 & East Marion & Arlington, VT & 95 & 1.1 & 0.8 & 0.00 \\
\hline Saint-Saens, Camille & 1835 & Paris & Paris & 86 & 32.1 & 16.9 & 0.74 \\
\hline Satie, Erik & 1866 & Honfleur & Paris & 59 & 26.3 & 18.2 & 0.61 \\
\hline Schmitt, Florent & 1871 & Blâmont & Paris & 87 & 20.2 & 13.3 & 0.60 \\
\hline Schoenberg, Arnold & 1874 & Vienna & Vienna & 77 & 6.6 & 4.6 & 0.34 \\
\hline Schreker, Franz & 1878 & Monaco & Vienna & 55 & 7.1 & 5.2 & 0.47 \\
\hline Schumann, Robert & 1810 & Zwickau & Leipzig & 46 & 5.1 & 1.7 & 0.02 \\
\hline Scryabin, Alexander & 1872 & Moscow & Moscow & 42 & 7.6 & 5.2 & 0.07 \\
\hline Sessions, Roger & 1896 & New York & Princeton & 89 & 0.4 & 0.3 & 0.00 \\
\hline Sibelius, Jean & 1865 & Hämeenlinna & Helsinki & 92 & 0.6 & 0.4 & 0.01 \\
\hline
\end{tabular}


TABLE A1: Summary of all Composers Included in the Study

\begin{tabular}{|c|c|c|c|c|c|c|c|}
\hline Name & $\begin{array}{l}\text { Birth } \\
\text { Year }\end{array}$ & City of Birth & $\begin{array}{l}\text { Primary Work } \\
\text { Location }\end{array}$ & Longevity & $\begin{array}{c}\text { Share of } \\
\text { Composers }\end{array}$ & $\begin{array}{l}\text { Number of } \\
\text { Composers }\end{array}$ & $\begin{array}{l}\text { Relative Time Spent } \\
\text { in Paris or Vienna }\end{array}$ \\
\hline Sinding, Christian & 1856 & Kongsberg & Oslo & 85 & 0.3 & 0.2 & 0.00 \\
\hline Smetana, Bedrich & 1824 & Litomysl & Prague & 60 & 3.5 & 1.4 & 0.00 \\
\hline $\begin{array}{l}\text { Stanford, Sir Charles } \\
\text { Villiers }\end{array}$ & 1852 & Dublin & London & 72 & 6.7 & 4.7 & 0.00 \\
\hline Strauss, Johann (Jr.) & 1825 & Vienna & Vienna & 74 & 8.5 & 3.8 & 0.77 \\
\hline Strauss, Richard & 1864 & Munich & Vienna & 85 & 4.8 & 3.5 & 0.26 \\
\hline Stravinsky, Igor & 1882 & St Petersburg & Los Angeles & 89 & 11.4 & 7.2 & 0.15 \\
\hline Sullivan, Sir Arthur & 1842 & London & London & 58 & 5.9 & 3.0 & 0.03 \\
\hline Szymanowski, Karol & 1882 & Tymoszowka & Warsaw & 55 & 7.2 & 5.6 & 0.15 \\
\hline Taneyev, Sergei & 1856 & Vladimir & Moscow & 59 & 4.4 & 2.7 & 0.00 \\
\hline $\begin{array}{l}\text { Tchaikovsky, Pyotr } \\
\text { II'yich }\end{array}$ & 1840 & Kamsko-Votkinsk & Moscow & 53 & 3.7 & 1.8 & 0.00 \\
\hline Thomas, Ambroise & 1811 & Metz & Paris & 85 & 36.7 & 14.5 & 0.73 \\
\hline Thomson, Virgil & 1896 & Kansas City & New York & 93 & 22.5 & 6.9 & 0.16 \\
\hline Varese, Edgard & 1883 & Paris & New York & 82 & 14.3 & 8.9 & 0.16 \\
\hline $\begin{array}{l}\text { Vaughan Williams, } \\
\text { Ralph }\end{array}$ & 1872 & Down Ampney & London & 86 & 4.9 & 3.1 & 0.00 \\
\hline Verdi, Giuseppe & 1813 & Roncole & Milan & 88 & 10.8 & 4.5 & 0.11 \\
\hline Villa-Lobos, Heitor & 1887 & Rio de Janeiro & Rio de Janeiro & 72 & 8.0 & 4.7 & 0.22 \\
\hline Vogel, Wladimir & 1896 & Moscow & Zurich & 87 & 5.5 & 1.8 & 0.00 \\
\hline Wagner, Richard & 1813 & Leipzig & Zurich & 70 & 5.0 & 1.6 & 0.04 \\
\hline Webern, Anton & 1883 & Vienna & Vienna & 62 & 5.6 & 4.1 & 0.47 \\
\hline Wellesz, Egon & 1886 & Vienna & Oxford & 88 & 3.4 & 2.6 & 0.34 \\
\hline Wolf, Hugo & 1860 & Windischgraz & Vienna & 43 & 7.9 & 4.6 & 0.47 \\
\hline Wolf-Ferrari, Ermanno & 1876 & Venice & Venice & 72 & 1.0 & 0.7 & 0.00 \\
\hline $\begin{array}{l}\text { Zemlinsky, Alexander } \\
\text { von }\end{array}$ & 1872 & Vienna & Vienna & 69 & 6.6 & 4.5 & 0.35 \\
\hline d'Indy, Vincent & 1851 & Paris & Paris & 81 & 27.9 & 18.0 & 0.70 \\
\hline
\end{tabular}


TABLE A2: Important Cities for Music Composers

Primary destination

(in composers)

Paris

38

Vienna $\quad 13$

London $\quad 8$

Moscow 7

Berlin 6

Milan 4

Leipzig 4

Prague 4

Rome 4

Budapest 3 
Table A3: Longevity and Birth Centrality (Reduced-Form)

\begin{tabular}{lc}
\hline \hline & Longevity \\
& OLS \\
\hline Birth Centrality & 0.019 \\
& $(4.862)$ \\
\hline Time of Birth Effects & Yes \\
Country of Birth Effects & Yes \\
Observations & 144 \\
$\mathrm{R}^{2}$ & 0.127
\end{tabular}

Notes: Standard errors are clustered at the main destination level and reported in parentheses. Each specification contains a constant which is not reported. $* * * \mathrm{p}<0.01, * * \mathrm{p}<0.05, * \mathrm{p}<0.1$. 
TABLE A4: Robustness Checks on Main Measure of Competition: Longevity ${ }^{\mathrm{a}}$.

Longevity

\begin{tabular}{|c|c|c|c|c|c|c|c|c|}
\hline & $\begin{array}{l}\text { Migration } \\
\text { History }\end{array}$ & Illness & $\begin{array}{l}\text { Below- } \\
\text { Average } \\
\text { Quality }\end{array}$ & $\begin{array}{c}\text { Important } \\
\text { Output } \\
\text { (Age }<30 \mathrm{yr})\end{array}$ & Pandemics & $\begin{array}{c}\text { War } \\
\text { Controls }\end{array}$ & $\begin{array}{l}\text { Composers } \\
\text { Served in Army } \\
\text { Excluded }\end{array}$ & Birth Year \\
\hline Number of Composers ${ }^{b}$ & $\begin{array}{c}-2.417 * * * \\
(0.71)\end{array}$ & $\begin{array}{c}-2.293 * * * \\
(0.7898)\end{array}$ & $\begin{array}{c}-2.097 * * \\
(0.873)\end{array}$ & $\begin{array}{c}-2.212 * * \\
(0.885)\end{array}$ & $\begin{array}{c}-2.319 * * * \\
(0.719)\end{array}$ & $\begin{array}{l}-2.266^{* * *} \\
(0.71)\end{array}$ & $\begin{array}{c}-2.003 * * * \\
(0.702)\end{array}$ & $\begin{array}{c}-2.146^{* * *} \\
(0.63)\end{array}$ \\
\hline (Number of Composers) $^{2}$ & $\begin{array}{c}0.079 * * \\
(0.033)\end{array}$ & $\begin{array}{c}0.081 * * \\
(0.037)\end{array}$ & $\begin{array}{c}0.068 \\
(0.047)\end{array}$ & $\begin{array}{c}0.084 * \\
(0.042)\end{array}$ & $\begin{array}{c}0.069^{*} \\
(0.034)\end{array}$ & $\begin{array}{c}0.071 * * \\
(0.033)\end{array}$ & $\begin{array}{l}0.059^{*} \\
(0.032)\end{array}$ & $\begin{array}{c}0.08 * * * \\
(0.029)\end{array}$ \\
\hline $\begin{array}{l}\text { Number of moves across } \\
\text { countries }\end{array}$ & $\begin{array}{c}0.189 \\
(0.239)\end{array}$ & & & & & & & \\
\hline $\begin{array}{l}\text { Majority of Share of Life } \\
\text { spent as 'below } \\
\text { average composer' }\end{array}$ & & & $\begin{array}{l}-3.372 \\
(2.989)\end{array}$ & & & & & \\
\hline $\begin{array}{l}\text { Important Works Written } \\
\quad(\text { Age }<30 \mathrm{yr})\end{array}$ & & & & $\begin{array}{c}0.256 \\
(0.286)\end{array}$ & & & & \\
\hline $\begin{array}{l}\text { Number of years } \\
\text { composer exposed to } \\
\text { active war }\end{array}$ & & & & & & $\begin{array}{c}1.178 \\
(4.129)\end{array}$ & & \\
\hline Birth Year & & & & & & & & $\begin{array}{c}0.267 * * * \\
(0.06)\end{array}$ \\
\hline Time of Birth Effects & Yes & Yes & Yes & Yes & Yes & Yes & Yes & No \\
\hline Country of Birth Effects & Yes & Yes & Yes & Yes & Yes & Yes & Yes & Yes \\
\hline Observations & 144 & 140 & 144 & 97 & 141 & 144 & 138 & 144 \\
\hline $\mathrm{R}^{2}$ & 0.14 & 0.129 & 0.147 & 0.131 & 0.147 & 0.139 & 0.126 & 0.204 \\
\hline
\end{tabular}

Notes: The dependent variable is longevity. ${ }^{a}$ Robust standard errors clustered at the geographic level are reported in parentheses. Each specification contains a constant (not reported). ${ }^{\mathrm{b}}$ Measures the lifetime average of composers located in the same city.

$* * * p<0.01, * * p<0.05, * p<0.1$. 
TABLE A5: Longevity and Geographic Clustering - Further Robustness Tests

\begin{tabular}{|c|c|c|c|c|c|c|c|c|}
\hline & \multicolumn{4}{|c|}{ Panel A: Additional Occupation } & \multicolumn{4}{|c|}{ Panel B: Interacting Competition with Quality } \\
\hline & (1) & $(2)$ & (3) & (4) & $(1)$ & $(2)$ & $(3)$ & (4) \\
\hline Number of Composers & $\begin{array}{l}-1.981 * * \\
(0787)\end{array}$ & & & & $-2.2 * * *$ & & & \\
\hline (Number of Composers) $^{2}$ & $\begin{array}{l}0.061^{*} \\
(0.036)\end{array}$ & & & & $\begin{array}{l}0.08 * * \\
(0.033)\end{array}$ & & & \\
\hline Share of Composers & & $\begin{array}{c}-0.958 * * \\
(0.472)\end{array}$ & & & & $\begin{array}{l}-0.968 * \\
(0.482)\end{array}$ & & \\
\hline$(\text { Share of Composers) })^{2}$ & & $\begin{array}{l}0.013 \\
(0.01)\end{array}$ & & & & $\begin{array}{c}0.015 \\
(0.011)\end{array}$ & & \\
\hline Relative Time Spent in & & & $-0.489 * *$ & & & & $-0.501 * * *$ & \\
\hline Clusters & & & $(0.183)$ & & & & $(0.174)$ & \\
\hline $\begin{array}{l}\text { (Relative Time Spent in } \\
\text { Clusters) })^{2}\end{array}$ & & & $\begin{array}{c}0.007 * * * \\
(0.002)\end{array}$ & & & & $\begin{array}{c}0.007 * * * \\
(0.002)\end{array}$ & \\
\hline Quality of Composers & & & & $\begin{array}{c}-0.219 * \\
(0.116)\end{array}$ & & & & $\begin{array}{c}-0.252 * \\
(0.141)\end{array}$ \\
\hline (Quality of Composers) $^{2}$ & & & & $\begin{array}{c}0.001 \\
(0.001)\end{array}$ & & & & $\begin{array}{c}0.001 \\
(0.001)\end{array}$ \\
\hline Occupation: Performer & $\begin{array}{l}-5.734 \\
(3.821)\end{array}$ & $\begin{array}{l}-6.108 \\
(4.122)\end{array}$ & $\begin{array}{c}-8.309 * * \\
(3.512)\end{array}$ & $\begin{array}{l}-6.499 \\
(3.878)\end{array}$ & & & & \\
\hline Occupation: Conductor & $\begin{array}{l}3.513^{*} \\
(1.960)\end{array}$ & $\begin{array}{l}3.172 \\
(2.029)\end{array}$ & $\begin{array}{l}3.857^{*} \\
(2.162)\end{array}$ & $\begin{array}{c}2.819 \\
(2.126)\end{array}$ & & & & \\
\hline Occupation: Teacher & $\begin{array}{l}4.365 \\
(2.94)\end{array}$ & $\begin{array}{c}4.491 \\
(2.707)\end{array}$ & $\begin{array}{c}3.889 \\
(2.676)\end{array}$ & $\begin{array}{l}5.002 * \\
(2.863)\end{array}$ & & & & \\
\hline Murray’s Index & & & & & $\begin{array}{c}0.09 \\
(0.107)\end{array}$ & $\begin{array}{c}0.074 \\
(0.013)\end{array}$ & $\begin{array}{c}0.055 \\
(0.123)\end{array}$ & $\begin{array}{l}0.205 \\
(0.34)\end{array}$ \\
\hline Number of Composers $x$ & & & & & $-0.021 * *$ & & & \\
\hline Index & & & & & $(0.008)$ & & & \\
\hline Share of Composers $\times$ & & & & & & $-0.009 * *$ & & \\
\hline Index & & & & & & $(0.003)$ & & \\
\hline Relative Time Spent in & & & & & & & -0.002 & \\
\hline Clusters $\times$ Index & & & & & & & $(0.003)$ & \\
\hline Quality of Composers $\times$ & & & & & & & & -0.002 \\
\hline Index & & & & & & & & $(0.004)$ \\
\hline Time of Birth Effects & Yes & Yes & Yes & Yes & Yes & Yes & Yes & Yes \\
\hline Country of Birth Effects & Yes & Yes & Yes & Yes & Yes & Yes & Yes & Yes \\
\hline Observations & 144 & 144 & 144 & 144 & 144 & 144 & 144 & 144 \\
\hline $\mathrm{R}^{2}$ & 0.16 & 0.145 & 0.172 & 0.112 & 0.147 & 0.14 & 0.12 & 0.115 \\
\hline
\end{tabular}

Notes: The dependent variable is longevity. Regressions are OLS. Robust standard errors clustered at the geographic level are reported in parentheses. Each specification contains a constant (not reported). 'Number of Composers' measures the lifetime average of composers located in the same city. 'Share of Composers' measures the lifetime average share of composers located in the same city. 'Relative time spent in Clusters' measures the share of a composer's life that he spent in Paris or Vienna. 'Quality of Composers' is measured as the sum of Murray's index scores of composers located in the same time and place.

$* * * \mathrm{p}<0.01, * * \mathrm{p}<0.05, * \mathrm{p}<0.1$. 